\title{
DISCOVERY LEARNING DALAM MATA KULIAH TEORI BELAJAR DAN PEMBELAJARAN UNTUK MENUMBUHKAN KEMAMPUAN PENEMUAN DIRI (SELF INVENTION) MAHASISWA
}

\author{
Wanda Nugroho Yanuarto \\ Universitas Muhammadiyah Purwokerto \\ pos-el : wandanugrohoyanuarto@ump.ac.id
}

\begin{abstract}
ABSTRAK
Penelitian ini bertujuan untuk mengetahui sejauh mana proses pembelajaran menggunakan discovery learning pada mata kuliah Teori Belajar dan Pembelajaran. Selain itu juga pembelajaran yang dilakukan untuk melihat kemampuan penemuan diri (Self invention) mahasiswa. Penelitian yang akan dilakukan adalah penelitian studi kasus metode deskriptif kualitatif. Penelitian ini dilakukan di Program Studi Pendidikan Matematika FKIP (Fakultas Keguruan dan Ilmu Pendidikan) UMP (Universitas Muhammadiyah Purwokerto). Penelitian dilaksanakan selama 4 bulan, dimulai dari bulan Mei sampai Agustus 2015. Populasi dari penelitian ini yaitu mahasiswa semester II yang mengambil mata kuliah Teori Belajar dan Pembelajaran, program studi Pendidikan Matematika Universitas Muhammadiyah Purwokerto yang berjumlah 92 mahasiswa. Dari populasi tersebut diambil 1 kelas teori, yaitu kelas IIB berjumlah 46 mahasiswa. Hasil penelitian ini didapatkan bahwa menggunakan discovery learning mahasiswa mampu mengembangkan kemampuan penemuan diri mereka. Didasarkan dari aspek langkah pengajaran discovery learning, mahasiswa mampu mengikuti pembelajaran dengan maksimal, sedangkan dari observasi kelas didapatkan mahasiswa dapat menyerap dan belajar sebanyak $83 \%$.
\end{abstract}

Kata kunci : discovery learning, teori belajar dan pembelajaran dan kemampuan penemuan diri (self invention)

\section{ABSTRACT}

The study aims to determine the extent to which the learning process uses discovery learning in the subject of Theory of Learning. In addition, learning is also done to see the ability of students' self invention. The research that will be conducted is a qualitative descriptive case study method (Creswell, 2012; Fraenkel, 2010). This research was carried out in the Mathematics Education Program FKIP (Teacher Training and Education Faculty) UMP (Muhammadiyah University of Purwokerto). The study was conducted for 4 months, starting from May to August 2015. The population of this study were second semester students who took the subject of Learning and Learning Theory, the Mathematics Education program at the Muhammadiyah University of Purwokerto which totaled 92 students. From this population, 1 theory class was taken, namely the class IIB was 46 students. The results of this study found that using discovery learning students are able to develop their self-discovery abilities. Based on the steps of discovery learning teaching, students are able to follow learning to the maximum, while from classroom observations students can absorb and learn as much as $83 \%$.

Keywords : discovery learning, theory of learning and self invention

\section{PENDAHULUAN}

Pembelajaranmatematika

hendaknya diarahkan agar mahasiswa mampu secara mandiri menyelesaikan masalah-masalah matematika ataupun masalah-masalah yang lain yang 
diselesaikan dengan bantuan matematika. Untuk lebih meningkatkan kemampuan diri sebagai pengajar profesional, mahasiswa perlu mengetahui teori belajar yang dikemukakan beberapa ahli pendidikan dan aplikasinya dalam pembelajaran matematika.

Tidak hanya tingkat kedalaman konsep yang diberikan kepada mahasiswa tetapi harus disesuaikan dengan tingkat kemampuannya, cara penyampaian materi pun demikian pula. Dosen harus mengetahui tingkat perkembangan mental mahasiswa dan bagaimana pengajaran yang harus dilakukan sesuai dengan tahap-tahap perkembangan tersebut. Pembelajaran yang tidak memperhatikan tahap perkembangan mental mahasiswa besar kemungkinan akan mengakibatkan mahasiswa mengalami kesulitan, karena apa yang disajikan tidak sesuai dengan kemampuan dalam menyerap materi yang diberikan.

Pada mata kuliah Teori Belajar dan Pembelajaran yang disajikan untuk mahasiswa semester 2 Pendidikan Matematika Universitas Muhammadiyah Purwokerto memiliki berbagai kendala yang dihadapi. Kendala tersebut sudah dialami oleh dosen pada semester 1. Mahasiswa dengan tingkat kematangan mental belum cukup untuk memenuhi kebutuhan belajarnya di tingkat perguruan tinggi juga belum mengetahui betul bagaimana cara belajar yang efektif guna meningkatkan kemampuan akademik dan sosial mereka. Berbagai masalah yang dihadapi diantaranya: 1) mahasiswa belum bisa menggunakan kemampuan individu mereka untuk belajar mandiri dan menggali kognisi mereka secara benar; 2) proses pembelajaran di kelas yang masih pasif, sehingga mahasiswa belum mampu untuk mengkomunikasikan ide dan gagasan mereka; dan 3) dampak dari proses komunikasi yang masih kurang mengakibatkan keaktifan di kelas juga rendah.

Dari permasalahan yang dihadapi oleh dosen pengampu mata kuliah Teori Belajar dan Pembelajaran tersebut, dibuatlah suatu rancangan pembelajaran yang dapat mengakomodir semua permasalahan yang ada. Solusi yang ada begitu menjadi pokok penting dalam pembelajaran di kelas, karena pengetahuan tentang teori belajar dalam sistem penyampaiaan materi dalam kelas penting, sehingga setiap model pengajaran harus selalu disesuaikan dengan teori-teori belajar yang dikemukakan oleh ahli pendidikan. Beberapa teori belajar psikologi diaplikasikan dalam pendidikan, dan diungkapkan bagaimana implikasinya dalam pembelajaran matematika.

Di dalam proses belajar, Bruner mementingkan keaktifan dari tiap mahasiswa, dan mengenal dengan baik adanya perbedaan kemampuan. Untuk menunjang proses belajar perlu lingkungan memfasilitasi rasa ingin tahu mahasiswa pada tahap eksplorasi. Lingkungan ini dinamakan Discovery Learning Environment, yaitu lingkungan dimana mahasiswa dapat melakukan eksplorasi, penemuanpenemuan baru yang belum dikenal. Lingkungan seperti ini bertujuan agar mahasiswa dalam proses belajar dapat berjalan dengan baik dan lebih aktif.

Proses belajar matematika yang dilakukan di program studi Pendidikan Matematika, Universitas Muhammadiyah 
hendaknya disajikan berdasarkan prinsip kemandirian dan mendukung kemampuan mahasiswa untuk mencari konsep dari belajar itu sendiri sebagai proses belajar mereka. Untuk menciptakan suasana belajar dimana mahasiswa dapat mencari ide dan konsep belajar matematika mereka sendiri perlu didukung oleh model pembelajaran yang dapat efektif untuk menyelesaikan masalah tersebut.

$\begin{array}{ccc}\text { Discovery } & \text { learning } & \text { yang } \\ \text { didefinisikan } & \text { sebagai } & \text { proses }\end{array}$ pembelajaran yang terjadi bila mahasiswa tidak disajikan dengan pelajaran dalam bentuk finalnya, akan tetapi diharapkan mengorganisasi sendiri. Sebagaimana pendapat Bruner, bahwa:

"Discovery learning can be defined as the learning that takes place when the student is not presented with subject matter in the final form, but rather is required to organize it him self", (Emetembun, 1986:103).

Dasar ide Bruner ialah pendapat dari Piaget yang menyatakan bahwa anak harus berperan aktif dalam belajar di kelas. Bruner memakai model belajar yang disebut Discovery Learning, dimana siswa mengorganisasi bahan yang dipelajari dengan suatu bentuk akhir (Dalyono, 1996). Discovery learning adalah memahami konsep, arti, dan hubungan, melalui proses intuitif untuk akhirnya sampai kepada suatu kesimpulan (Budiningsih, 2005).

Discovery dilakukan melalui observasi, klasifikasi, pengukuran, prediksi, penentuan dan inferi. Proses tersebut disebut cognitive process sedangkan discovery itu sendiri adalah the mental process of assimilating conceps and principles in the mind (Sund, 2001:219)

Penggunaan Discovery learning, dapat merubah kondisi belajar yang pasif menjadi aktif dan kreatif. Mengubah pembelajaran yang teacher oriented ke student oriented. Mengubah modus ekspositori mahasiswa hanya menerima informasi secara keseluruhan dari dosen ke modus discovery mahasiswa menemukan informasi sendiri. Oleh karena itu, dengan menggunakan Discovery Learning secara berulang-ulang di mata kuliah Teori Belajar dan Pembelajaran program studi Pendidikan Matematika Universitas Muhammadiyah Purwokerto diharapkan dapat menumbuhkan kemampuan penemuan diri (self invention) dan keaktifan mahasiswa

\section{METODE PENELITIAN}

Penelitian yang akan dilakukan adalah penelitian studi kasus metode deskriptif kualitatif (Creswell, 2012; Fraenkel, 2010). Metode ini akan meneliti status sekelompok manusia berkaitan dengan suatu obyek, suatu kondisi, suatu pemikiran ataupun suatu peristiwa yang terjadi pada saat sekarang ini. Tujuan yang ingin dicapai adalah mendapatkan gambaran mengenai kemampuan penemuan diri (self invention) dan keaktifan mahasiswa program studi Pendidikan Matematika

Universitas Muhammadiyah Purwokerto ketika belajar dalam mata kuliah Teori Belajar dan Pembelajaran sampai peneliti mendapatkan gambaran yang sistematis, faktual dan akurat berdasarkan faktafakta atau gejala-gejala yang telah diselidiki.

Penelitian ini dilakukan di Program Studi Pendidikan Matematika FKIP (Fakultas Keguruan dan Ilmu Pendidikan) UMP (Universitas Muhammadiyah Purwokerto).Penelitian dilaksanakan selama 4 bulan, dimulai dari bulan Mei sampai Agustus 2015. Populasi dari penelitian ini yaitu mahasiswa semester II yang mengambil mata kuliah Teori Belajar dan Pembelajaran, program studi Pendidikan Matematika Universitas Muhammadiyah Purwokerto yang 
berjumlah 92 mahasiswa. Dari populasi tersebut diambil 1 kelas teori, yaitu kelas IIB berjumlah 46 mahasiswa. Alasan pemilihan kelas dikarenakan kelas tersebut memiliki komplektisitas permasalahan lebih banyak. Kelas diberi perlakuan pembelajaran menggunakan Discovery Learning untuk menumbuhkan kemampuan penemuan diri (Self Invention) dan keaktifan di kelas.

Metode pengambilan data pada penelitian ini terdiri dari tes dan wawancara. Tes dilakukan di akhir semester. Hasil tes ini kemudian dianalisis secara mendalam. Hasil dari analisis tes inilah yang menggambarkan kemampuan penemuan diri (self invention) dan keaktifan mahasiswa. Tes yang diberikan mengambil beberapa materi yang sekiranya dapat menampung dan mengetahui dengan kemampuan penemuan diri (self invention) dan keaktifan mahasiswa yang dituangkan secara tulisan. Sedangkan wawancara digunakan sebagai salah satu teknik pengumpulan data sebagai pelengkap data dari tes. Peneliti akan mengetahui dari para mahasiswa hal-hal yang lebih mendalam mengenai apa yang telah dilakukannya selama menjalani tes.

Teknik analisis data menggunakan data reduction. Data yang diperoleh dari hasil penelitian dikumpulkan dan dipilih secara teliti dan rinci. Data yang tidak diperlukan disingkirkan untuk kemudian diseleksi data yang penting untuk dianalisis. Teknik data reduction (Reduksi Data) berarti merangkum halhal yang dibutuhkan, memilih hal-hal yang pokok, memfokuskan hal-hal yang penting, mencari tema dan pola, dan membuang yang tidak perlu (Sugiyono, 2012). Berdasarkan data yang telah direduksi, dianalisis, dan kemudian disajikan, peneliti menarik kesimpulan tentang kemampuan penemuan diri (self invention) dan keaktifan mahasiswa program studi Pendidikan Matematika Universitas Muhammadiyah Purwokerto mata kuliah Teori Belajar dan Pembelajaran. Penarikan kesimpulan menggunakan metode induksi (Miles \& Huberman, 1992) yaitu penarikan kesimpulan dari hal-hal yang umum ke yang khusus. Dari berbagai data yang mempunyai karakteristik tertentu, peneliti mengambil kesimpulan umum.

\section{HASIL DAN PEMBAHASAN}

\section{Discovery Learning dalam Mata Kuliah Teori Belajar dan Pembelajaran}

Teori Belajar dan Pembelajaran adalah salah satu pembelajaran yang diajarkan di pendidikan matematika untuk mahasiswa semester II pada semester genap. Mata kuliah ini mengajarkan banyak teori tentang bagaimana seharusnya mahasiswa belajar. Belajar bukan hanya sekedar mentransfer ilmu dari sumbernya menuju otak manusia, tetapi ilmu tentang bagaimana manusia belajar dijelaskan dalam mata kuliah ini. Penulis memandang bahwa mata kuliah ini menjadi suatu tolak ukur bagaimana mahasiswa dapat berhasil pada semester berikutnya, dan bagaimana mahasiswa dapat memahami dengan baik makna dari belajar itu sendiri. Oleh karena itu penulis membuat sebuah model dalam pembelajaran di kelasnya berupa pembelajaran yang dilakukan dari konsep yang mereka temukan sendiri dengan temannya kemudian dimunculkan dan dipresentasikan di depan kelas agar setiap mahasiswa memiliki pemahaman dan konsep yang sama tentang suatu hal. Pembelajaran yang mungkin terjadi adalah discovery learning.

Beberapa prosedur yang harus dilaksanakan dalam kegiatan 
pembelajaran di mata kuliah Teori Belajar dan Pembelajaran adalah sebagai berikut:

Stimulation (pemberian rangsangan)

Pertama-tama pada tahap ini mahasiswa dihadapkan pada sesuatu yang menimbulkan kebingungannya, kemudian dilanjutkan untuk tidak memberi generalisasi, agar timbul keinginan untuk menyelidiki sendiri. Disamping itu guru dapat memulai kegiatan perkuliahan dengan mengajukan pertanyaan, anjuran membaca buku, dan aktivitas belajar lainnya yang mengarah pada persiapan pemecahan masalah.

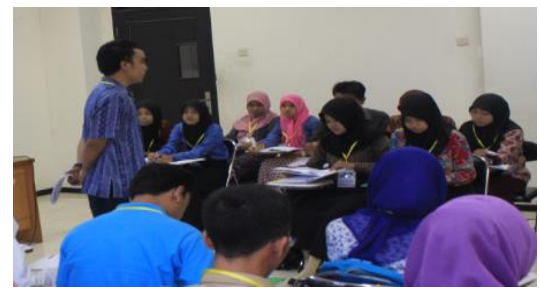

Gambar 1. Dosen memberikan pertanyaan di awal perkuliahan sebagai dasar pemberian rangsangan pada mahasiswa

Stimulasi pada tahap ini berfungsi untuk menyediakan kondisi interaksi belajar yang dapat mengembangkan dan membantu siswa dalam mengeksplorasi bahan. Dalam hal ini Bruner memberikan stimulation dengan menggunakan teknik bertanya yaitu dengan mengajukan pertanyaanpertanyaan yang dapat menghadapkan siswa pada kondisi internal yang mendorong eksplorasi. Dengan demikian seorang dosen harus menguasai teknik-teknik dalam memberi stimulus kepada mahasiswa agar tujuan mengaktifkan mahasiswa untuk mengeksplorasi dapat tercapai.

\begin{tabular}{l} 
Problem Statement (identifikasi \\
masalah) \\
\multicolumn{2}{c}{ Setelah dilakukan stimulasi } \\
langkah selanjutya adalah dosen \\
memberi kesempatan \\
mahasiswa untuk mengidentifikasi
\end{tabular}

sebanyak mungkin agenda-agenda masalah yang relevan dengan bahan pelajaran, kemudian salah satunya dipilih dan dirumuskan dalam bentuk hipotesis (jawaban sementara atas pertanyaan masalah), sedangkan menurut permasalahan yang dipilih itu selanjutnya harus dirumuskan dalam bentuk pertanyaan, atau hipotesis, yakni pernyataan (statement) sebagai jawaban sementara atas pertanyaan yang diajukan.

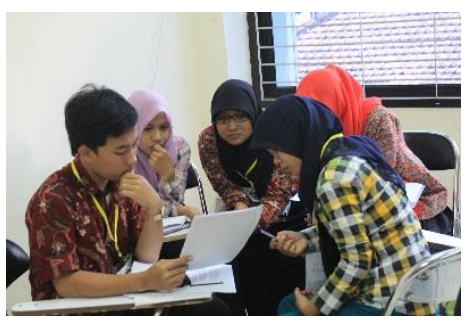

Gambar 2. Dosen memberikan lembar kerja mahasiswa (LKM) sebagai bahan untuk mengidentifikasi masalah pada pokok bahasan terkait

Memberikan kesempatan mahasiswa untuk mengidentifikasi dan menganalisis permasasalahan yang mereka hadapi, merupakan teknik yang berguna dalam membangun mahasiswa agar mereka terbiasa untuk menemukan suatu masalah.

Data Collection (pengumpulan masalah)

Ketika eksplorasi berlangsung dosen juga memberi kesempatan kepada mahasiswa untuk mengumpulkan informasi sebanyak-banyaknya yang relevan untuk membuktikan benar atau tidaknya hipotesis (Syah, 2004:244). Pada tahap ini berfungsi untuk menjawab pertanyaan atau membuktikan benar tidaknya hipotesis. 


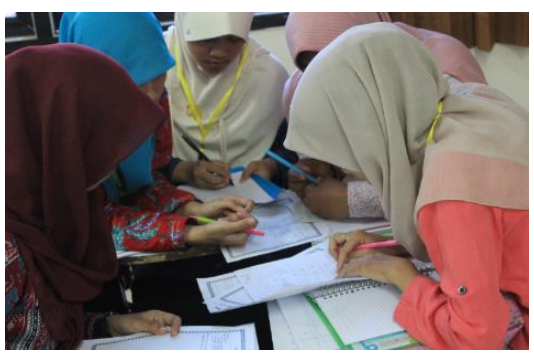

Gambar 3. Mahasiswa melakukan data collection atas maasalah yang mereka hadapi dari catatan dan uji coba secara berkelompok

Dengan demikian mahasiswa
diberi mengumpulkan (collection) berbagai informasi yang relevan, membaca literatur, mengamati objek, melakukan uji coba sendiri dan sebagainya. Konsekuensi dari tahap ini adalah mahasiswa belajar secara aktif untuk menemukan sesuatu yang berhubungan dengan permasalahan yang dihadapi, dengan demikian secara tidak disengaja mahasiswa menghubungkan masalah dengan pengetahuan yang telah dimiliki.

Data Processing (pengolahan data)

Menurut Syah (2004:244)

pengolahan data merupakan kegiatan mengolah data dan informasi yang telah diperoleh mahasiswa baik melalui wawancara, observasi, dan sebagainya, lalu ditafsirkan. Semua informasi hasil bacaan, wawancara, observasi, dan sebagainya, semuanya diolah, diacak, diklasifikasikan, ditabulasi, bahkan bila perlu dihitung dengan cara tertentu serta ditafsirkan pada tingkat kepercayaan tertentu (Djamarah, 2002:22).

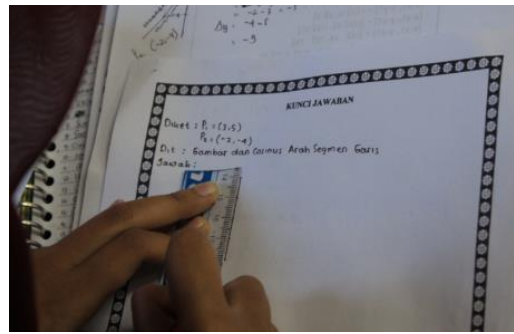

Gambar 4. Pengolahan data dilakukan dengan mencermati masalah dan mencobanya secara diskusi dan mandiri
Data processing disebut juga dengan pengkodean/ kategorisasi yang berfungsi sebagai pembentukan konsep dan generalisasi. Dari generalisasi tersebut mahasiswa akan mendapatkan pengetahuan baru tentang alternatif jawaban/ penyelesaian yang perlu mendapat pembuktian secara logis. Verification (pembuktian)

Pada tahap ini siswa melakukan pemeriksaan secara cermat untuk membuktikan benar atau tidaknya hipotesis yang ditetapkan tadi dengan temuan alternatif, dihubungkan dengan hasil data processing (Syah, 2004:244). Verification menurut Bruner, bertujuan agar proses belajar akan berjalan dengan baik dan kreatif jika guru memberikan kesempatan kepada siswa untuk menemukan suatu konsep, teori, aturan atau pemahaman melalui contohcontoh yang ia jumpai dalam kehidupannya.

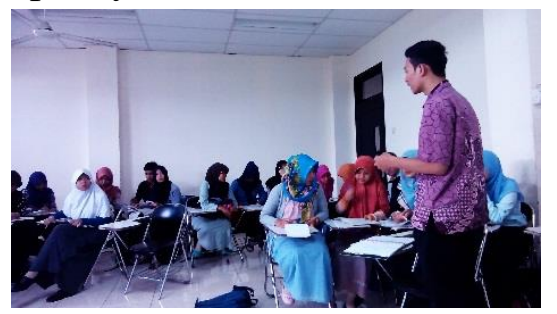

Gambar 5. Pembuktian dilakukan dengan cara proses mempresentasikan hasil diskusi dan memproses tanggapan dari kelompok lain

Berdasarkan hasil pengolahan dan tafsiran, atau informasi yang ada, pernyataan atau hipotesis yang telah dirumuskan terdahulu itu kemudian dicek, apakah terjawab atau tidak, apakah terbukti atau tidak.

Generalization (menarik kesimpulan)

Tahap generalisasi/ menarik kesimpulan adalah proses menarik sebuah kesimpulan yang dapat dijadikan prinsip umum dan berlaku untuk semua kejadian atau masalah yang sama, dengan memperhatikan hasil verifikasi (Syah, 2004:244). Berdasarkan hasil verifikasi maka 
dirumuskan prinsip-prinsip yang mendasari generalisasi.

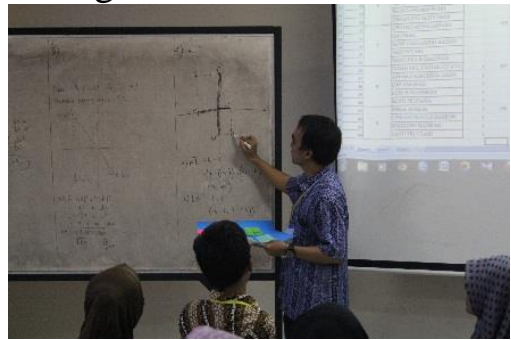

Gambar 6. Generalisasi dilakukan secara bersama-sama antara mahasiswa dengan dosen agar terjadi satu persepsi yang sama

Setelah menarik kesimpulan mahasiswa harus memperhatikan proses generalisasi yang menekankan pentingnya penguasaan materi atas makna dan kaidah atau prinsip-prinsip yang luas yang mendasari pengalaman seseorang, serta pentingnya proses pengaturan dan generalisasi dari pengalaman-pengalaman itu.

\section{Kemampuan Penemuan Diri (Self Invention)}

Observasi kemampuan penemuan diri (self invention) dilaksanakan untuk mencaritahu bagaimana kemampuan penemuan diri pada mahasiswa dimiliki untuk setiap pembelajaran dengan menggunakan discovery learning. Dari hasil observasi kemampuan penemuan diri didapatkan sebagai berikut: 1) Mahasiswa terlihat menyajikan data/informasi yang diketahui direpresentasikan ke dalam bentuk narasi, diagram, grafik, atau tabel dalam pembelajaran. Hal ini disimpulkan dari hasil observasi yang dilakukan bahwa observer menyatakan bahwa tugas yang diberikan dosen dikerjakan dalam kelompok; 2) Mahasiswa terlihat berusaha mengerjakan masalah yang diberikan dosen, terlihat dari hasil observasi yang dilakukan oleh observer, bahwa observer melihat bahwa semua kelompok sudah berusaha menyelesaikan masalah yang diberikan dalam pembelajaran secara diskusi kelompok maupun mandiri; 3)
Mahasiswa terlihat dapat menyelesaikan masalah yang dihadapi dengan langkahlangkah penyelesaian secara runtut, hal ini sesuai hasil dari observer bahwa ada kelompok yang mengolah informasi dari berbagai sumber sudah tepat.

Dari hasil observarsi juga terlihat bahwa observer sudah dapat menilai bahwa mahasiswa terlihat menyelesaikan masalah yang dihadapi dalam representasi diagram, grafik, atau tabel. Secara keseluruhan dapat disimpulkan bahwa kemampuan penemuan diri (self invention) mahasiswa yang dilihat dari hasil observasi adalah mahasiswa dapat menggunakan kemampuan tersebut dalam mata kuliah Teori Belajar dan Pembelajaran. Terbukti dari hasil observasi, hasil analisa observer menilai bahwa pembelajaran dapat berjalan dengan baik dan kemampuan penemuan diri dapat ditumbuhkembangkan dalam pembelajaran.

Dalam kegiatan wawancara, pelaksanaan dibagi menjadi 2 tim, yaitu tim penulis dan 1 tim dari dosen anggota. Tiap tim akan mewawancarai 3 mahasiswa dengan masing-masing kategori dengan kemampuan penemuan diri tinggi, sedang, dan rendah. Wawancara dilakukan di ruang Laboratorium Workshop Matematika. Berikut disajikan bagaimana pengambilan kategori kemampuan representasi matematis:

Tabel 1. Pengambilan kategori kemampuan penemuan diri (self invention)

\begin{tabular}{|c|c|c|}
\hline $\begin{array}{l}\text { Jumlah } \\
\text { mahasiswa }\end{array}$ & Kategori & $\begin{array}{l}\text { Perwakilan tiap } \\
\text { kelompok }\end{array}$ \\
\hline \multirow{3}{*}{$\begin{array}{l}46 \\
\text { mahasiswa } \\
\text { kelas IIB }\end{array}$} & $\begin{array}{l}\text { KPD } \\
\text { tinggi }\end{array}$ & M-13, M-37, M-21 \\
\hline & $\begin{array}{l}\text { KPD } \\
\text { sedang }\end{array}$ & M-05, M-41, M-02 \\
\hline & $\begin{array}{l}\text { KPD } \\
\text { rendah }\end{array}$ & M-21, M-38, M-17 \\
\hline
\end{tabular}

Dari hasil wawancara didapatkan beberapa hal sebagai berikut: 1) Stimulus (pemberian rangsang/stimuli), kegiatan belajar dimulai dengan memberikan pertanyaan yang 
merangsang berfikir mahasiswa, menganjurkan dan mendorongnya untuk membaca buku dan aktivitas belajar lain yang mengarah pada persiapan pemecahan masalah; 2) Problem Statement (mengidentifikasi masalah), memberikan kesempatan mahasiswa untuk mengidentifikasi sebanyak mungkin masalah yang relevan dengan bahan belajar kemudian memilih dan merumuskan dalam bentuk hipotesa; 3) Data Collection (pengumpulan data), memberikan kesempatan kepada para si belajar untuk mengumpulkan informasi yang relevan sebanyak-banyaknya untuk membuktikan benar/tidaknya pernyataan; 4) Data Processing (pengolahan data), yakni mengolah data yang telah diperoleh mahasiswa melalui kegiatan wawancara, observasi dan lainlain kemudian data tersebut ditafsirkan; 5) Verifikasi, mengadakan pemeriksaan secara cermat untuk membuktikan benar dan tidaknya hipotesis yang diterapkan dan dihubungkan dengan hasil dan processing; dan 6) Generalisasi, mengadakan penarikan kesimpulan untuk dijadikan prinsip umum dan berlaku untuk semua kejadian atau masalah yang sama dengan memperhatikan hasil verifikasi.

Selain itu, untuk mendapatkan beberapa informasi lainnya dilakukan observasi kegiatan mahasiswa. Hal ini dilakukan untuk mengetahui apakah keaktifan mahasiswa dapat terlihat dan tumbuh dengan baik dan sesuai rencana. Dari hasil observasi keaktifan mahasiswa didapatkan sebagai berikut: 1) Mendengar, dalam proses belajar yang sangat menonjol adalah mendengar dan melihat. Apa yang mahasiswa dengar dapat menimbulkan tanggapan dalam ingatan-ingatan, yang turut dalam membentuk jiwa sesorang untuk bertanya dan berpendapat mengenai suatu ide atau gagasan tertentu di dalam kelas; 2) Melihat, mahasiswa dapat mneyerap dan belajar 83\% dari penglihatannya. Melihat berhubungan dengan penginderaan terhadap objek nyata, seperti peraga atau demonstrasi. Untuk meningkatkan keaktifan mahasiswa dalam belajar melalui proses mendengar dan melihat, sering digunakan alat bantu dengar dan pandang, atau yang sering di kenal dengan istilah media atau alat peraga. Sehingga di dalam kelas, mahasiswa dituntut untuk menggunakan media atau alat peraga tertentu.

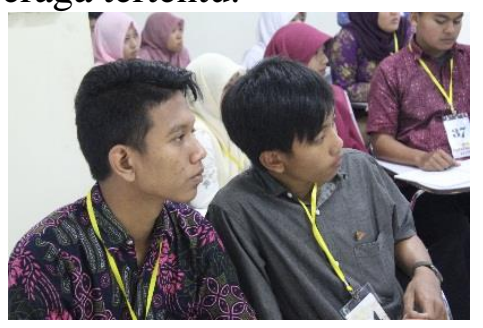

Gambar 7. Potret keaktifan mahasiswa dalam proses pembelajaran dilihat dari indicator mendengar dan melihat

Selanjutnya 3) Mengolah ide, dalam mengolah ide mahasiswa melakukan proses berpikir atau proses kognisi. Dari keterangan yang disampaikan kepadanya, baik secara lisan maupun secara tulisan, serta dari proses penginderaan yang lain yang kemudian mahasiswa mempersepsi dan menanggapinya; 4) Menyatakan ide, tercapainya kemampuan melakukan proses berpikir yang kompleks ditunjang oleh kegiatan belajar melalui pernyataan atau mengekspresikan ide. Ekspresi ide ini dapat diwujudkan melalui kegiatan diskusi, melakukan eksperimen, atau melalui proses penemuan melalui kegiatan atau presentasi.

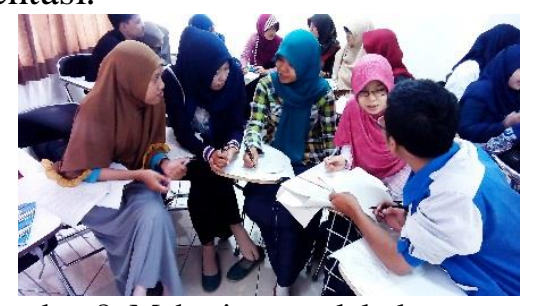

Gambar 8. Mahasiswa melakukan proses berpikir dengan mengungkapkan ide dan gagasan di depan kelas maupun dengan anggota kelompoknya 
Melakukan latihan, bentuk tingkah laku yang sepatutnya dapat dicapai melalui proses belajar, di samping tingkah laku kognitif, tingkah laku afektif (sikap) dan tingkah laku psikomotorik (keterampilan).

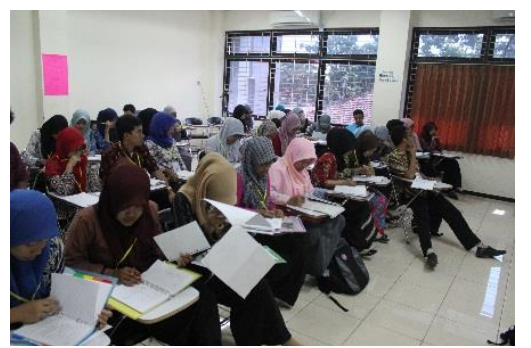

Gambar 9. Proses pengorganisasian pikiran mahasiswa dilaksanakan dan dinilai pada proses latihan

\section{KESIMPULAN}

Pembelajaran yang telah dirancang oleh dosen model dan para dosen observer telah dapat memunculkan kemampuan penemuan diri (self invention) dan keaktifan mahasiswa. Dari hasil dan pembahasan dalam penelitian ini maka dapat disimpulkan bahwa pembelajaran pada mata kuliah Teori Belajar dan Pembelajaran dengan model Discovery Learning dapat membantu perkembangan kemampuan penemuan diri (self invention) mahasiswa dan keaktifan mahasiswa. Pengembangan pembelajaran dilakukan sesuai dengan kebutuhan pada mahasiswa.

Perkembengan dunia pendidikan terus berlangsung sejalan dengan tuntutan hidup manusia untuk menjawab perkembangan ilmu pengetahuan dan teknologi yang semakin hari semakin maju dan kompleks. Dunia pendidikan juga dituntut untuk peka terhadap perubahan dan perkembangan sekecil apa pun dalam dunia ilmu pengetahuan dan teknologi. Dalam konteks ini peran dosen tidaklah kecil. Dosen atau guru sebagai ujung tombak pelaksana pendidikan terdepan dituntut untuk terus mengembangkan pengetahuan, kemampuan serta keterampilannya. Oleh karena itu disaran kepada semua yang berhubungan dengan dunia pendidikan dan khususnya dosen/ guru dapat membaca dan memahami Teoriteori belajar dan pembelajaran.

\section{DAFTAR PUSTAKA}

Budiningsih. (2005). Discovery learning sebagai pemecahan masalah pendidikan Indonesia. Bandung : Bineka Cipta Utama

Creswell, J. W. (2012). Educational Research. Boston: Pearson Education.

Dalyono. (1996). Model pembelajaran discovery learning. Jakarta: Karya Asih Persada

Emetembun. (1986). Penemuan sebagai Discovery learning dalam belajar. Yogyakarta: Media Raya

Fraenkel, R. J., \& Wallen, E. N. (2010). How To Design And Evaluate Research in Education. Boston: Mc Graw Hill

Hamzah. (2003). Teori belajar dan pembelajaran sebagai jiwa pendidikan. Jakarta: Media Utama

Joolingen, W.R. van, \& Jong, T. de. (1997). An extended dual search space model of scientific discovery learning. Instructional Science, 25, 307-346.

Miles\& Huberman. (1992). Penelitian kualitatif dalam pendidikan. Jakarta: Cipta Reka Utama

Stuart \& Sudeen (1998). How to overcome self invention. New Jersey: Routledge

Sugiyono. (2012). Memahami Penelitian Kualitatif. Bandung: Alfabeta.

Sugiyono. (2012). Metode Penelitian Pendidikan. Bandung: Alfabeta

Suherman, E, et al. 2003. Strategi Pembelajaran Matematika Kontemporer. Bandung: JICA. 
Sund. (2001). Discovery learning as role learning model. California: Hill \& Co

Syah, M., (1996). Psikologi Pendidikan Suatu Pendekatan Baru. Bandung: PT Remaja Rosdakarya. Syamsudini. (2012). Aplikasi Metode Discovery Learning dalam Meningkatkan Kemampuan Memecahkan Masalah, Motivasi Belajar dan Daya Ingat Siswa. 